\title{
False-positive uptake on radioiodine whole-body scan due to bronchiectasis
}

\author{
Raquel Espírito Santo, ${ }^{1,2}$ Pedro Marques, ${ }^{1}$ Maria João Bugalho ${ }^{1}$
}

${ }^{1}$ Instituto Português de Oncologia de Lisboa Francisco Gentil EPE, Lisboa, Portugal ${ }^{2}$ Hospital Curry Cabral, Centro Hospitalar de Lisboa Central, Lisboa, Portugal

\section{Correspondence to}

Professor Maria João Bugalho, mjbugalho@ipolisboa. min-saude.pt

Accepted 26 October 2015
CrossMark

To cite: Espírito Santo $R$, Marques P, Bugalho MJ. BMJ Case Rep Published online: [please include Day Month Year] doi:10.1136/ bcr-2015-213169

\section{DESCRIPTION}

A 71-year-old man underwent a total thyroidectomy with central lymph node dissection, for papillary thyroid carcinoma (PTC) without angioinvasion and with no poorly differentiated areas, staged as pT1aN1aMx. The patient had ablation Iodine-131 (I-131) treatment with $3.7 \mathrm{GBq}(100 \mathrm{mCi})$. Post-therapeutic whole-body scan (WBS) revealed mild cervical uptake of I-131 compatible with small thyroid remnant and uptake in the lungs, particularly in the left inferior lung lobe (figure 1A), suggesting metastatic involvement by PTC. On this occasion, the stimulated thyroglobulin (Tg) was $1.1 \mathrm{ng} / \mathrm{mL}$ (Thyroid-Stimulating Hormone $(\mathrm{TSH})=67.59 \mu \mathrm{UI} /$ $\mathrm{mL}$ ), in the absence of $\mathrm{Tg}$ antibodies.

Chest CT scan ruled out the hypothesis of lung metastases of PTC (figure 1B, C) and demonstrated exuberant saccular bronchiectasis, mostly in the left lung.

The patient remained under TSH-suppressive therapy and now, after 3 years of follow-up, there is evidence of neither structural nor biochemical disease.

I-131 WBS is a highly valuable examination for management of patients with differentiated thyroid carcinoma. ${ }^{1}$ However, radioiodine uptake is not specific for thyroid tissue. Retention of radioiodine can occur as a result of structural or functional changes in any part of the body located along the route of radioiodine excretion or blood pooling. ${ }^{2}$

Recognition of false-positives and artefacts in radioiodine WBS is critical to avoid costly

\section{Learning points}

- Post radioiodine treatment, whole-body scan enables identification of ectopic uptake and staging of patients with differentiated thyroid carcinoma, and should be interpreted on the basis of clinical, serum thyroglobulin and other imaging findings.

- lodine-131 activity detected outside the thyroid bed is usually attributed to metastatic lesions.

- False-positive images may rarely occur and their recognition is important to prevent costly additional investigation and inappropriate therapy.

Figure 1 (A) Post-therapeutic whole-body I-131 scan showing uptake in the thyroid bed and lungs, particularly in the left inferior lung lobe (B and C). Chest CT scan revealing saccular bronchiectasis, mostly in the left lung. 
additional investigations and inappropriate therapies, preventing unnecessary exposure to further radiation. ${ }^{3}$

This case highlights the need for a cautious interpretation of 'abnormal' WBS, with consideration given to the clinical context and laboratory findings (either stimulated or suppressed $\mathrm{Tg}$ ), and eventual further clarification through cross-sectional imaging.

Competing interests None declared.

Patient consent Obtained.

Provenance and peer review Not commissioned; externally peer reviewed.

\section{REFERENCES}

1 Cooper DS, Doherty GM, Haugen BR, et al. Revised American Thyroid Association management guidelines for patients with thyroid nodules and differentiated thyroid cancer, American Thyroid Association (ATA) Guidelines Taskforce on Thyroid Nodules and Differentiated Thyroid Cancer. Thyroid 2009;19:1167-214.

2 Oh JR, Ahn BC. False-positive uptake on radioiodine whole-body scintigraphy: physiologic and pathologic variants unrelated to thyroid cancer. Am J Nucl Med Mol Imaging 2012;2:362-85.

3 Triggiani V, Moschetta M, Giagulli VA, et al. Diffuse 1311 lung uptake in bronchiectasis: a potencial pitfall in the follow up of differenciated thyroid carcinoma. Thyroid 2012;22:1287-90.

Copyright 2015 BMJ Publishing Group. All rights reserved. For permission to reuse any of this content visit http://group.bmj.com/group/rights-licensing/permissions.

BMJ Case Report Fellows may re-use this article for personal use and teaching without any further permission.

Become a Fellow of BMJ Case Reports today and you can:

- Submit as many cases as you like

- Enjoy fast sympathetic peer review and rapid publication of accepted articles

- Access all the published articles

- Re-use any of the published material for personal use and teaching without further permission

For information on Institutional Fellowships contact consortiasales@bmjgroup.com

Visit casereports.bmj.com for more articles like this and to become a Fellow 